\title{
POLA KOMUNIKASI ANTARA SEKOLAH DAN ORANGTUA SISWA BERKEBUTUHAN KHUSUS (SBK) DI SEKOLAH INKLUSI
}

\author{
Farah Farida Tantiani \\ Universitas Negeri Malang \\ tantiani@yahoo.com
}

\begin{abstract}
Since 2009, inclusive school programs were established in many schools in Indonesia, from pre-school to higher education. Inclusive school is school who accommodate students with various ability and character due to common right to study. Meaning students with special needs may be students of regular school and study the same material as other students. Challenges emerge for school and students' parents, particularly parents of students with special needs. These challenges have been overcome by effective communication done by school and parents of students with special needs. Knowledge of how to communicate effectively and communication method is needed by school and parents, thus the same aim can be reached to help students with special needs develop optimally at inclusive school.
\end{abstract}

Keywords: Effective Communication, Inclusive School, Students with Special Needs

\begin{abstract}
Abstrak
Sejak 2009, di Indonesia mulai marak program sekolah inklusi diberbagai jenjang pendidikan sejak jenjang prasekolah hingga universitas. Sekolah inklusi adalah sekolah yang menampung siswa dengan berbagai kemampuan dan karakter karena dianggap memiliki hak yang sama untuk belajar. Hal ini berarti siswa berkebutuhan khusus (SBK) dapat menjadi siswa di sekolah reguler dan mempelajari materi yang sama dengan siswa lainnya. Hal ini tentu saja menimbulkan banyak tantangan bagi pihak sekolah dan orangtua siswa, terutama pada orangtua SBK. Tantangan ini dapat mulai diatasi dengan membuka jalur komunikasi yang efektif antara pihak sekolah dan orangtua SBK. Prinsip-prinsip komunikasi yang efektif serta metode komunikasi perlu diketahui antara pihak sekolah dan orangtua sehingga dapat dicapai kesamaan tujuan untuk membantu SBK berkembang optimal di sekolah inklusi.
\end{abstract}

Kata Kunci: Komunikasi Efektif, Sekolah Inklusif, Siswa Berkebutuhan Khusus

Diterima: 30 April 2015 Direvisi: 27 Mei 2015 Disetujui: 10 Juni 2015 


\section{PENDAHULUAN}

Saat ini, tidak lagi sulit ditemukan anak-anak berkebutuhan khusus (ABK) bermain bersama teman-teman mereka di sekolah reguler. ABK yang dianggap memerlukan pendidikan dan perangkat yang berbeda dari teman-temannya yang tidak berkebutuhan khusus, dahulu diarahkan untuk bersekolah di sekolah luar biasa (SLB). Akan tetapi dengan semangat bahwa pendidikan adalah hak semua anak, maka sekolah reguler mulai membuka diri untuk sama-sama berkembang dengan menerima siswa berkebutuhan khusus (SBK). Sistem pengajaran SBK di sekolah reguler tetap dibedakan dalam beberapa aspek tergantung dari kebutuhan khusus anak, tetapi dalam kegiatan belajar yang dianggap tidak membutuhkan instruksi khusus, SBK tetap mengikuti kegiatan belajar bersama teman-teman di kelas reguler.

Sejak tahun 1990-an terjadi gerakan menuju pendidikan luar biasa di sekolah-sekolah reguler dan kelas-kelas umum. Gerakan ini disebabkan hadirnya prinsip normalisasi atau berusaha menyediakan kondisi paling tidak terbatas (least restrictive environment) bagi SBK. Kondisi ini berarti lingkungan seputar SBK berusaha membuat SBK dalam situasi kehidupan sehari-hari yang normal, seminimal mungkin dalam pembatasan di lingkungan rumah maupun sekolah. Hal ini memberikan kemungkinan bagi SBK untuk bersekolah di sekolah reguler dengan kesempatan yang sama untuk mengikuti pendidikan dengan anak-anak lainnya (Mangunsong, 2009).

Dengan kondisi seperti ini, tentu saja timbul berbagai tantangan pada berbagai pihak terlibat. Sekolah, tentu harus siap dengan segala sarana dan prasarananya. Pada sarana tentu saja perlu ditambahkan atau dimodifikasi untuk memenuhi kebutuhan SBK. Misalnya, pada sekolah yang tadinya mungkin menggunakan tangga saja, jika mulai menerima SBK tuna daksa, mereka perlu mulai memikirkan untuk menambahkan lift atau jalan naik yang lurus. Dengan demikian maka siswa yang memakai kursi roda mudah mengakses kelasnya secara mandiri. Selain itu, guru sebagai teman belajar anak juga perlu menambah pengetahuannya tentang SBK dan cara belajar mereka. Para siswa reguler pun perlu mulai bisa menerima keberadaan SBK di kelas mereka. SBK yang mungkin butuh waktu lebih lama untuk bisa memahami materi atau saat bekerja kelompok perlu diterangkan kembali instruksi yang diberikan. SBK pun harus dapat menyesuaikan diri dengan kebiasaan-kebiasaan untuk belajar mandiri dan bekerja lebih giat dalam 
mencapai tujuan bersama teman-teman mereka. Perangkat sekolah lain seperti satpam atau tata usaha pun harus bisa siap dalam berinteraksi dengan mereka. Mitra kerjasama sekolah, yaitu orangtua, baik orangtua siswa reguler maupun SBK, perlu paham pula bagaimana kondisi belajar di sekolah yang akan saling mendukung perkembangan optimal anak-anak mereka.

Saat ini, beberapa masalah yang sering hadir di sekolah inklusi adalah masalah penyesuaian diri, baik pada guru maupun pada siswanya. Guru di sekolah inklusi sering merasa kurang memiliki pengetahuan dan pelatihan yang dapat membuat mereka merasa lebih percaya diri menghadapi SBK di kelas. Siswa kelas reguler seringkali merasa tidak paham dengan keberadaan mereka sehingga di beberapa sekolah inklusi timbul masalah pertemanan seperti bullying. Pada SBK, mereka pun harus menyesuaikan diri dengan hadirnya guru pendamping (shadow teacher) saat sedang belajar di kelas padahal temantemannya tidak menggunakan guru pendamping. Orangtua siswa juga perlu menyesuaikan diri dengan mendampingi anak-anak mereka, termasuk menjawab pertanyaan-pertanyaan mengenai berbagai hal yang dialami di sekolah. Mereka juga perlu ikut berdiskusi dengan guru kelas maupun guru pendamping mengenai pendampingan yang tepat di rumah untuk mendukung perkembangan anak-anak mereka di semua aspek perkembangannya.

Semangat normalisasi bagi SBK di bidang pendidikan dalam bentuk sekolah inklusi memerlukan kerja sama yang baik antara pihak sekolah dan orangtua SBK agar SBK dapat memperoleh manfaat belajar di sekolah inklusi, bukan malah mendapatkan masalah karena berada di sana. Pola kerjasama yang baik tentulah memerlukan komunikasi yang baik antara pihak sekolah dan dan orangtua/keluarga SBK. Pola komunikasi pulalah yang seringkali menimbulkan kesalahpahaman antara pihak sekolah dan orangtua siswa, sehingga perlu diketahui bagamana pola komunikasi yang efektif untuk membantu perkembangan optimal SBK di sekolah inklusi.

\section{Siswa Berkebutuhan Khusus (SBK)}

Siswa Berkebutuhan Khusus (SBK) menurut Ormrod (2011) adalah siswa yang berbeda dari kelompok siswa lainnya yang memerlukan materi belajar yang diadaptasi khusus serta pelatihan-pelatihan untuk memaksimalkan belajar dan pencapaian mereka. Banyak anak SBK yang memiliki hambatan di aspek kognitif, sosial atau fisik yang dapat mempengaruhi performa atau 
kinerja mereka dalam belajar di sekolah umum. Beberapa kondisi yang dinyatakan sebagai siswa kebutuhan khusus adalah sebagai berikut:

1. Siswa dengan kesulitan akademis atau kognitif khusus. Biasanya siswa ini memiliki kesulitan untuk memproses informasi yang berkaitan dengan kemampuan berpikir atau tuntutan akademis di sekolahnya. Beberapa diantaranya adalah siswa yang mengalami kesulitan belajar, kesulitan memusatkan perhatian seperti attention deficit hypercativity disorder (ADHD) atau hambatan dalam berbicara dan berkomunikasi.

2. Siswa dengan masalah sosial atau perilaku. Pada siswa dengan kebutuhan khusus ini biasanya masalah mereka adalah dalam hal pengekspresikan diri. Hal ini membuat mereka sulit beradaptasi dan menyesuaikan diri dalam pergaulan dengan teman-temannya atau saat berinteraksi dengan pengajarnya. Akibatnya, mereka mengalami hambatan dalam kinerjanya di sekolah/kelas. Yang tergolong dalam kategori ini adalah anak dengan spektrum autisme dan anak yang mengalami masalah dalam emosi dan perilakunya.

3. Siswa dengan keterlambatan dalam fungsi kognitif dan sosialnya. Pada siswa ini, mereka mengalami kesulitan dalam mencapai prestasi yang sesuai tahapan usianya dan biasanya perkembangannya setara dengan tahap anak yang usianya lebih rendah dibandingkan usia mereka. Contoh dari kategori ini adalah anak-anak dengan keterbelakangan mental.

4. Siswa yang memiliki tantangan fisik atau sensori. Pada siswa ini biasanya karena ada masalah fisik dan medis, misalnya pada kecacatan fisik, gangguan penglihatan atau pendengaran.

5. Siswa yang memiliki perkembangan kognitif yang melebihi usianya. Pada siswa ini, biasanya perkembangannya sangat maju dalam salah satu area kemampuan atau lebih, misalnya pada anak-anak cerdas berbakat istimewa.

Dengan kondisi khusus yang mereka miliki, siswa-siswa ini memerlukan waktu untuk menyesuaikan diri saat di sekolah. Mereka juga perlu beradaptasi terhadap penjelasan dari guru, setting kelas maupun saat bermain dengan temanteman yang lain. Proses adaptasi mereka akan lebih baik jika didukung oleh komunikasi yang baik antara pihak sekolah, SBK serta orangtua SBK. 


\section{Sekolah Inklusi}

Ada beberapa bentuk penyelenggaraan sistem pembelajaran di sekolah umum, di antaranya adalah sistem pendidikan iklusif. Sistem pendidikan inklusif dibedakan dari istilah least restrictive environment (LRE) oleh Heward (2013). Menurutnya, inklusi berarti mendidik SBK dalam kelas pendidikan reguler sedangkan prinsip LRE mendidik SBK dalam kelas yang disetting semirip mungkin dengan kelas reguler. Hal ini juga dinyatakan oleh Mangunsong (2009) bahwa dalam pendidikan yang inklusif, sekolah diharapkan menyediakan kebutuhan bagi semua individu yang ada di dalam komunitasnya karena dianggap sebagai salah satu keragaman. Oleh karena itu, dalam lingkungan sekolah inklusif, sekolah harus mempertimbangkan kebutuhan semua orang, bukan hanya SBK yang menyesuaikan diri dengan setting sekolah yang ada.

Di Indonesia, menurut Peraturan Menteri Pendidikan Nasional Republik Indonesia no. 70 tahun 2009 pasal 1, yang dimaksud dengan pendidikan inklusif adalah sebuah sistem penyelenggaraan pendidikan yang memberikan kesempatan bagi peserta didik berkebutuhan khusus untuk mengikuti pendidikan dalam satu lingkungan bersama-sama dengan peserta didik pada umumnya. Dengan demikian, pemerintah meletakkan landasan hukum untuk mendukung sistem pendidikan inklusi diterapkan di Indonesia. Dalam rangka menerapkan pendidikan inklusi ini, sejak tahun 2004 pemerintah rutin menunjuk beberapa sekolah menjadi sekolah inklusi dan menyelenggarakan berbagai pelatihan bagi masing-masing penyelenggara pendidikan. Akan tetapi, seperti yang diutarakan oleh Mangunsong (2009), sampai saat ini, SBK masih menerima model pengajaran yang beragam, belum sepenuhnya sesuai dengan prinsip pendidikan inklusif, karena pihak penyelenggara pendidikan masih rancu antara menjalankan sistem pendidikan inklusi dengan integrasi.

Mangunsong (2009) menjelaskan bahwa sistem integrasi berbeda dengan sistem inklusi. Pada sistem integrasi, SBK mengikuti kelas/sekolah khusus lalu dipindahkan ke sekolah reguler ketika dianggap sudah siap. Pada sistem integrasi, SBK ditempatkan dalam satu kelas berdasarkan tingkat keberfungsiannya dan pengetahuannya, bukan usianya. Prinsip utama sistem integrasi adalah bahwa SBK harus menyesuaikan diri dengan ketentuan sistem dan aktivitas kelas reguler. Sedangkan pada sistem inklusi, semua siswa, termasuk ABK dianggap sama, yaitu sama-sama bervariasi, sehingga seperti yang sudah dijelaskan di paragraf sebelumnya, SBK tidak perlu —disiapkan॥ untuk dianggap berhak mengikuti pendidikan di kelas 
reguler. Hal ini menunjukkan ada tantangan tersendiri bagi pengambil kebijakan untuk menyiapkan kurikulum yang dapat mengakomodasi kebutuhan semua jenis siswa di kelas/sekolah inklusi.

\section{Keluarga dengan Anak Berkebutuhan khusus}

Pada orangtua yang memiliki anak terdiagnosis berkebutuhan khusus ditemukan bahwa mereka melalui tahapan emosi dan tantangan yang serupa saat mereka bereaksi dan menyesuaikan diri dengan kelahiran atau diagnosis yang diberikan pada anak mereka. Menurut penelitian dari Boushey serta penelitian dari Holland (dalam Heward, 2013) orangtua biasanya melalui tiga tahap reaksi emosi saat menerima diagnosis anak mereka: pertama, orangtua biasanya mengalami krisis emosi yang ditandai dengan syok, penyangkalan dan rasa tidak percaya. Periode awal ini diikuti dengan periode perasaan/emosi yang bergantian antara perasaan marah, rasa bersalah, depresi, malu, self-esteem yang rendah, penolakan terhadap anak atau overprotective. Sampai akhirnya orangtua dapat menerima dan menyesuaikan diri dengan kondisi anaknya.

Kochlar-Bryant (dalam Heward, 2013) menyebutkan bahwa orangtua yang memiliki ABK merupakan sumber utama pengetahuan tentang anaknya, baik kekuatan maupun kebutuhan dari sang anak. Orangtua juga melalui proses penyesuaian diri yang terus menerus dalam menghadapi kondisi anaknya sehingga selalu butuh dukungan dari orang lain di sekitar ABK untuk samasama mengusahakan perkembangan optimal bagi anak ABK. Orangtua ABK setidaknya memiliki sembilan peran dan tanggungjawab untuk dipenuhi yaitu sebagai pengasuh, pembimbing, orangtua pada saudara kandung ABK lainnya, istri/suami dari pasangannya, pemberi informasi untuk orang lain yang bertanya tentang kondisi anaknya dan mitra sekolah untuk perkembangan anaknya. Hal ini tentu berbeda dari orangtua yang tidak memiliki ABK.

\section{Pengembangan Kerjasama antara Sekolah dan Keluarga}

Melalui analisis dari hasil penelitian Yuniardi (2011) tentang masalah yang dialami pada sekolah-sekolah inklusi di Malang, ada keluhan dari guru bahwa mereka merasa bekerja sendiri, padahal pada sistem pendidikan inklusif, yang efektif adalah yang selalu ada keterkaitan antara keluarga, masyarakat dan siswanya. Hasil penelitian ini juga menyatakan pentingnya keterlibatan orangtua ABK dan masyarakat dalam proses pendidikan anak ABK. Hal ini juga senada dengan penelitian dari Blue-Banning dkk (dalam 
Heward, 2013) bahwa kerjasama yang efektif antara sekolah dan orangtua ditandai dengan keterlibatan keluarga untuk meraih tujuan bersama, yaitu untuk perkembangan optimal anak. Jadi orangtua menerima dukungan dari sekolah dalam bentuk pengetahuan dan sarana yang bisa membuat mereka berpartisipasi penuh sebagai mitra kerja sekolah dan pihak sekolah menerima masukan dari keluarga yang dapat mendukung mereka untuk mengajar dan memfasilitasi belajar anak secara lebih efektif. Salah satu kuncinya adalah menjalin komunikasi yang baik.

\section{Prinsip Komunikasi antara Sekolah dan Orangtua}

C.L Wilson (dalam Heward, 2013) merekomendasikan lima prinsip yang dapat diajadikan dasar untuk mengembangkan komunikasi efektif antara sekolah dan orangtua, yaitu:

1. Menerima Pernyataan Orangtua.

Hal ini berarti menyatakan secara verbal dan nonverbal bahwa informasi yang disampaikan oleh orangtua $\mathrm{ABK}$ adalah sesuatu hal yang berharga. Ini akan membuat orangtua lebih terbuka dan bebas mengutarakan apa yang diketahuinya karena mereka merasa dihargai. Bagi pihak sekolah, menghargai orangtua bukan berarti langsung menyetujui semua hal yang disampaikan oleh orangtua. Pihak sekolah juga dapat menyampaikan bagaimana perkembangan anak di sekolah. Jika terdapat informasi yang berbeda antara pihak sekolah dan pihak orangtua, diharapkan tidak ada sikap saling menyalahkan melainkan saling berdiskusi sehingga bisa diketahui apakah yang menyebabkan perbedaan informasi tersebut.

2. Mendengarkan dengan Aktif.

Seorang pendengar yang baik akan memberikan perhatian dan respon tekait pembicaran yang berlangsung. Ia akan memberikan perhatian pada isi pembicaraan, mengetahui siapa yang mengucapkan apa dan bagaimana pengucapannya. Hal ini penting karena seringkali pembicaraan antara pihak sekolah dan orangtua menyangkut kesepakatan pelaksanaan program belajar ABK. Pihak sekolah perlu mendengarkan dengan aktif sehingga bisa paham atas keberatan yang mungkin timbul atas usulan program dari sekolah dan orangtua perlu mendengarkan aktif untuk mengetahui bagiamana program tersebut akan dilaksanakan di rumah maupun di sekolah. Oleh karena itu, jika ada ketidaksepahaman, dapat segera dicari solusi yang paling baik untuk menjalankan program tersebut. 


\section{Bertanya dengan Efektif}

Ketika berkomunikasi dengan orangtua, pihak sekolah seyogyanya memakai model pertanyaan terbuka. Hal ini akan berguna menggali jawaban yang sifatnya informatif dan deskriptif. Pertanyaan terbuka lebih efektif dibanding model pertanyaan tertutup yang kemungkinan jawaban yang tergali darinya hanya ya atau tidak saja. Selain itu, pihak sekolah juga perlu tetap menjaga fokus perhatian pada masalah yang ada dan menghargai keinginan keluarga bahwa mungkin ada beberapa hal yang ingin dijaga kerahasiaannya. Inti dari pertanyaan pihak sekolah adalah untuk mencari tahu alasan utama terjadinya suatu masalah sehingga bisa dibuatkan program bersama orangtua yang mungkin dijalankan dengan bekerjasama.

4. Memberikan Dukungan

Penting bagi orangtua untuk mendengarkan berita baik tentang anak-anak mereka. Sekolah perlu menggambarkan dan menunjukkan pada orangtua tentang kemajuan yang dialami oleh anak mereka. Pihak sekolah perlu memberikan fokus pada apa yang berhasil dilakukan anak-anak tersebut dan kemajuan yang mereka buat selama belajar di kelas/sekolah.

5. Fokus pada Perkembangan SBK.

Pada setiap pembicaraan tentu perlu ada pembicaraan awal untuk mencairkan suasana. Akan tetapi perlu diupayakan agar pembicaraan lebih banyak membahas mengenai perkembangan siswa. Pihak sekolah juga perlu mengetahui orang-orang yang terlibat dalam perkembangan anak sehingga dapat membuat program kerjasama dijalankan dengan efektif.

\section{Metode Komunikasi Sekolah dan Keluarga ABK}

Heward (2013) menyatakan bahwa belum ditemukan satu metode yang dianggap efektif atau dapat digunakan untuk semua orangtua dan keluarga $\mathrm{ABK}$, sehingga cara yang paling baik adalah dengan memberikan berbagai metode komunikasi lalu mendiskusikan cara yang paling efektif dengan orangtua.

1. Pertemuan Tatap Muka Orangtua-Guru.

Pada metode komunikasi ini, orangtua dan guru bertatap muka, di mana masing-masing saling bertukar informasi dan saling berkoordinasi tentang usaha mereka untuk membantu ABK di rumah maupun di sekolah. Kelemahannya, metode ini seringkali berlangsung kaku dan 
tegang sehingga seringkali isi pesan komunikasi tidaklah tersampaikan. Pada sekolah yang ingin menyelenggarakan pertemuan tatap muka, Stephens \& Wolf (dalam Heward, 2013) memberikan panduan sebagai berikut:

a. Bangun rapport. Bagi orangtua, penting untuk memahami bahwa guru anaknya adalah guru yang peduli terhadap perkembangan anaknya. Dengan demikian, sebelum mulai membahas perkembangan anak, guru perlu menggunakan waktu untuk berbincang-bincang singkat guna membangun kepercayaan orangtua, sehingga perbincangan soal perkembangan anak akan lebih luwes.

b. Memperoleh informasi. Orangtua dapat memberikan informasi penting pada guru dalam memperbaiki pola belajar anak dan guru di sekolah kelak. Sehingga seperti pola komunikasi yang tadi sudah dijelaskan, diharapkan guru dapat menggunakan pertanyaan yang sifatnya terbuka untuk memperoleh informasi yang lebih deskriptif mengenai pola kebiasaan anak di rumah.

c. Memberikan informasi. Guru perlu memberikan banyak informasi tentang performa siswa di sekolah dengan bahasa yang mudah dipahami oleh orangtua. Informasi ini sebaiknya dilengkapi dengan data seperti hasil karya anak sehingga perkembangan anak selama belajar di sekolah dapat dilihat.

d. Buat kesimpulan dan tindakan lanjutan. Pertemuan ini haruslah diakhiri dengan kesimpulan mengenai diskusi yang sudah dilakukan dan semua keputusan yang dihasilkan dari diskusi tersebut. Pihak sekolah perlu melihat kembali strategi yang sudah disetujui selama pertemuan tatap muka dan mengindikasikan kegiatan-kegiatan apa yang sudah sama-sama disepakati untuk dilakukan. Beberapa sekolah melakukan pencatatan selama pertemuan lalu menggandakan catatan tersebut untuk disimpan oleh pihak sekolah dan pihak keluarga sambil mencatat waktu untuk pertemuan selanjutnya jika diperlukan.

2. Komunikasi tertulis

Pertemuan tatap muka antara pihak sekolah dan keluarga memang memberikan banyak keuntungan dan kemudahan. Akan tetapi pertemuan tatap muka ini seringkali tidak dapat dilakukan karena kesibukan pihak sekolah maupun keluarga SBK. Saat ini dikenal ada buku komunikasi di sekolah. Ini merupakan komunikasi tertulis antara pihak sekolah dan pihak keluarga. Untuk menggunakan metode komunikasi tertulis ini perlu kehatihatian karena guru perlu 
berkomunikasi dalam satu bahasa dengan orangtua, sedangkan lewat bahasa tulisan tidak dapat langsung diberikan umpan balik yang menyatakan bahwa kita paham atau tidak paham terhadap pesan yang disampaikan. Oleh karenanya, komunikasi tertulis hanya untuk menyampaikan informasi umum dan bukan untuk mendiskusikan hal-hal yang spesifik sehingga dapat terhindar salah paham antara pihak sekolah dan keluarga.

3. Komunikasi lewat telepon.

Komunikasi ini dapat digunakan jika ada hal-hal di dalam buku komunikasi yang tampaknya kurang jelas. Akan tetapi tetap disarankan untuk membahas hal-hal spesifik yang membutuhkan diskusi panjang lewat metode komunikasi tatap muka. Namun jika ternyata ada hal-hal penting yang harus segera diberitahukan lebih dahulu, bisa menggunakan komunikasi lewat media telepon ini.

4. Komunikasi lewat media e-mail dan text messaging.

Pola komunikasi antara pihak sekolah dan orangtua saat ini selain dengan pertemuan tatap muka juga dimungkinkan untuk menjalin komunikasi melalui e-mail atau melalui media sosial media seperti Whats App, Facebook, Blackberry Messenger, sms. Meskipun bentuk komunikasi yang berbeda-beda, tetapi prinsip dasar yang penting disepakati adalah harus tetap saling menghargai antara pihak sekolah dan pihak keluarga $A B K$, bahwa kerjasama mereka memiliki satu tujuan bersama yaitu untuk perkembangan optimal SBK.

\section{DISKUSI}

Berdasarkan deskripsi sebelumnya, maka dapat diuraikan beberapa kesimpulan sebagai berikut:

1. Sekolah inklusi adalah sekolah yang memungkinkan setiap orang untuk memperoleh pendidikan yang sama, termasuk memungkinkan ABK untuk berada di kelas reguler bersama dengan teman-temannya yang lain

2. Pola kerjasama antara sekolah dan orangtua SBK dibutuhkan karena saat ini pelaksanaan sekolah inklusi di Indonesia masih menghadapi banyak tantangan.

3. Bentuk kerjasama yang paling penting dikembangkan adalah bentuk komunikasi antara pihak sekolah dan orangtua SBK bahwa mereka samasama memiliki satu tujuan bersama, yaitu untuk perkembangan optimal SBK. 
4. Pola komunikasi antara pihak sekolah dan orangtua SBK harus memperhatikan saling menghargai satu sama lain serta saling memberi dukungan untuk perkembangan SBK. Metode komunikasi yang dapat digunakan adalah dalam bentuk tatap muka langsung, menggunakan media tulis seperti dalam buku komunikasi ataupun dengan menggunakan alat bantu teknologi seperti e-mail, sms, dan media sosial yang ada serta bisa pula menggunakan telepon.

\section{DAFTAR PUSTAKA}

Heward, W.H (2013), Exceptional Children: an Introduction to Special

Education, $10^{\text {th }}$ ed, Boston: Pearson Education, Inc.

Mangunsong, F (2009), Psikologi dan Pendidikan Anak Berkebutuhan Khusus, Jilid kesatu, Depok: LPSP3

Mendiknas RI (2009). Peraturan Menteri Pendidikan Nasional RI no.70 tahun 2009 tentang Pendidikan Inklusif bagi Peserta Didik yang memiliki Kelainan dan memiliki potensi Kecerdasan dan/atau Bakat Istimewa. Diunduh 30

Mei 2015 dari http://peduliinklusi.blogspot.com/2009/11/permendiknasno-70-tahun-2009-tentang.html

Ormrod, J.E (2011) Educational Psychology: Developing Learners, $7^{\text {th }}$ ed, Boston: Pearson Education, Inc.

Yuniardi, M.S (2011), Inclusive Education Focused on Resiliency, dalam Fakultas Psikologi UI (2011) The International Confrence on Psychology of Resilience proceeding, Depok: LPSP3 UI. 